\title{
Ways of conducting surveys in the student environment in remote format
}

\section{Formas de realizar encuestas en el entorno estudiantil en formato remoto}

\author{
Anna V. Lapshova \\ any19.10@mail.ru \\ https://orcid.org/0000-0001-7017-3589 \\ Minin Nizhny Novgorod State Pedagogical University, Nizhny Novgorod, Russia. \\ Olga I. Vaganova \\ vaganova_o@rambler.ru \\ https://orcid.org/0000-0001-8347-484X \\ Minin Nizhny Novgorod State Pedagogical University, Nizhny Novgorod, Russia. \\ Vyacheslav A. Ivanov \\ ivanov65@inbox.ru \\ https://orcid.org/0000-0001-5112-3789 \\ Plekhanov Russian University of Economics, Moscow, Russia. \\ Marina N. Bulaeva \\ bulaevamarina@mail.ru \\ https://orcid.org/0000-0002-9928-9451 \\ Minin Nizhny Novgorod State Pedagogical University, Nizhny Novgorod, Russia. \\ Maxim M. Kutepov \\ kmm-asb@mail.ru \\ https://orcid.org/0000-0002-5397-6168 \\ Minin Nizhny Novgorod State Pedagogical University, Nizhny Novgorod, Russia.
}

\begin{abstract}
The purpose of this article is to analyze the experience of conducting surveys in the student environment through the use of electronic educational resources. The article presents a survey of students about the performance of one of the most popular electronic tools Mentimeter today. The dynamics of the results of project activities of students using this service is traced. As a result, it was obtained that the use of Mentimeter makes it possible to conduct effective surveys, obtain automatic results and feedback on a specific issue, allowing you to build constructive activities in the student environment and form the professional competence of students.
\end{abstract}

Recibido: 18/08/21

Aceptado: $3 / 11 / 21$ 
Key Words: Mentimeter, survey, electronic tools, professional education, project activity.

\section{Resumen}

El propósito de este artículo es un análisis de la experiencia de realizar encuestas en el entorno estudiantil mediante el uso de recursos educativos electrónicos. El artículo presenta una encuesta a estudiantes sobre el desempeño de una de las herramientas electrónicas más populares de Mentimeter en la actualidad. Se rastrea la dinámica de los resultados de las actividades del proyecto de los estudiantes que utilizan este servicio. Como resultado se obtuvo que el uso de Mentímetro permite realizar encuestas efectivas, obtener resultados automáticos y retroalimentación sobre un tema específico, lo que le permite construir actividades constructivas en el entorno estudiantil y formar la competencia profesional de los estudiantes.

Palabras clave: mentímetro, encuesta, herramientas electrónicas, formación profesional, actividad de proyectos.

\section{Introduction}

Building a process of communication and interaction with the audience, promptly obtaining data in modern conditions is becoming one of the most important tasks of professional education since the learning process is actively developing in an electronic environment.

Universities are actively looking for the most relevant ways to conduct surveys in the student environment in a remote format. The main criterion is the ease of processing the data obtained in the course of monitoring the educational results of students.

One of the most popular electronic tools in the educational environment - Mentimeter offers ample opportunities in organizing and conducting instant feedback polls, advanced data analytics.

The tool exports analytical data to PDF or spreadsheets, moderates questions and answers. There is a possibility of integration with Microsoft Excel.

Each survey has its unique identification code. Therefore, survey participants have the option not to register for the test (Smirnova et al., 2020). Each student uses their device to access the resource, enter the code and answer questions or vote (Bogdanova \& Fedorova, 2020).

Mentimeter is a solution that allows you to interact with a wide target audience online. A wide audience can be represented by a different number of people (Aniskin et al., 2020). And this electronic instrument is one of those that makes it easy to do.

The functionality of the tool allows you to: 
- polls;

- quizzes;

- voting (Vaganova et al., 2020).

Mentimeter is an English-language platform, but the program's interface is intuitive and therefore easy to use (Bulaeva, et al., 2018).

Google forms are in high demand in conducting current and mid-term surveys. Conducting surveys and arranging them in tables is completely free, therefore, this electronic tool is also popular among students (Dobudko et al., 2019).

The Kahoot service is also relevant today for testing the knowledge component. Allows you to conduct surveys and quizzes, organize both individual and group activities (Vaganova et al., 2019). Kahoot allows you to create both short and capacious questions, and more extended ones that require more serious preparation, therefore, surveys created in Kahoot are carried out for both current and midterm control (Dronova, 2020).

Universities independently choose the tools for conducting surveys, it all depends on specific needs and tasks (Shashlo et al., 2018).

The resources we have presented are not exhaustive, but the most common among those used by higher education institutions.

Each of the tools provides the ability to create different surveys in the learning process. There is a need to identify the effectiveness of electronic services for conducting surveys in the student environment.

\section{Theoretical framework}

The fastest and most versatile way to write tests is to use Google Forms. Each form is a web page that hosts a questionnaire or quiz. Google forms allow you to conduct briefs, votes, and collect feedback (Yarygin et al., 2019).

The advantage is the ease of use, 24/7 accessibility. The form is always in the cloud. Everyone can choose an individual design. Also, Google forms are adapted for mobile devices and you can create and edit polls from your phone (Kiseleva et al., 2019). Forms provide an opportunity for professional registration of statistics on responses (automatically).

The Kahoot service settings allow you to set the difficulty level of the question, the response time interval, add a description and tags to the question, automatically go to the next question, set the order of the questions, download the received data to a computer in Microsoft Excel format and Google disk (Pichugina \& Bondarchuk, 2019). 
When using this service, a survey is created with the ability to add photos and videos (Kidina, 2020). The teacher gives the student a virtual room number, which is generated by the system itself and shows the task on the screen. Students enter the virtual room from their devices (while competitive results are displayed on the main screen) (Vaganova et al., 2019). Each participant is assigned corresponding points (Shcerbakova \& Shcerbakova, 2019).

Mentimeter differs in that the survey is accompanied by maximum clarity through presentation (Pinkovetskaia et al., 2020).

Mentimeter is a service that offers its users various tariff plans, including a free one, which provides the functions necessary for conducting a high-quality survey for use (Demidov et al., 2016 b). There are several template options for creating a survey:

- multiple choice (Demidov et al., 2016a);

- open answers;

- word clouds (Kharytonov et al., 2019);

- scales;

ranking (Demidov et al., 2016b);

choice of answer cards and others (Chulanova, 2018).

The advantages of the tool in question are as follows:

- organization of fast feedback in real time (Ivanova \& Korostelev, 2019);

- interactive feedback increases the involvement of students in the educational process (Nagovitsyn et al., 2020);

- the possibility of visualization, a high level of visibility of information for a wide audience (Tezer et al., 2019).

Using Mentimeter provides many benefits for its users in mastering educational material. Students, developing a survey on their own, immerse themselves in the topics studied and form the ability for professional self-development. Maximum visibility forms a clearer idea of the topic being studied.

\section{Methodology}

The study was conducted in 2018, 2019 and 2020 among 358 senior students. Over several semesters, students have used Mentimeter's project-based capabilities to conduct surveys. Their results were recorded.

High, average and satisfactory results were identified by the point-rating system.

Upon completion of the design work, students were asked to rate the performance of Mentimeter on a scale from 1 to 4 . They were asked to answer the question: "How do you 
assess the use of Mentimeter in the implementation of your project activities?" Where 1 the tool does not unambiguously show its effectiveness in project activities; 2 - the instrument does not show its effectiveness to a greater extent; 3 - the tool is more effective in project activities; 4 - the tool shows the absolute effectiveness in project activities.

\section{Results and discussion}

In Mentimeter, students were offered various types of polls:

- multiple choice with ready-made answer options;

- open questions;

- word clouds;

- quizzes.

The trainees independently used the capabilities of the tool in their project activities.

The results of the students were assessed by the point-rating system.

High result: 86-100 points; average result: $71-85$ points; satisfactory result: 55-70 points.

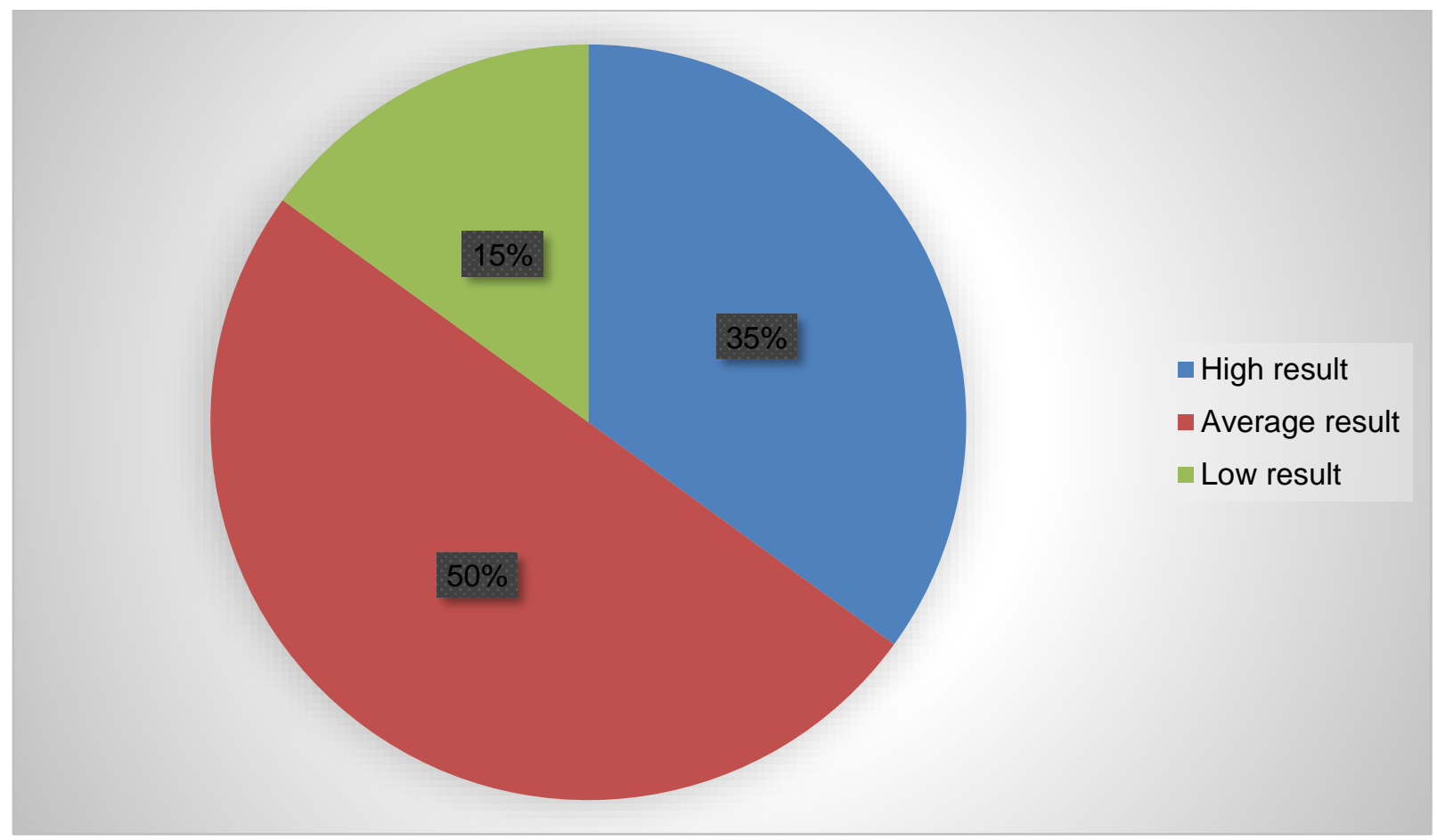

Fig. 1. Results of using Mentimeter in student project activities in 2018.

In 2018 , the number of respondents with an average result was $50 \%$, and $35 \%$ of students had a high result. 


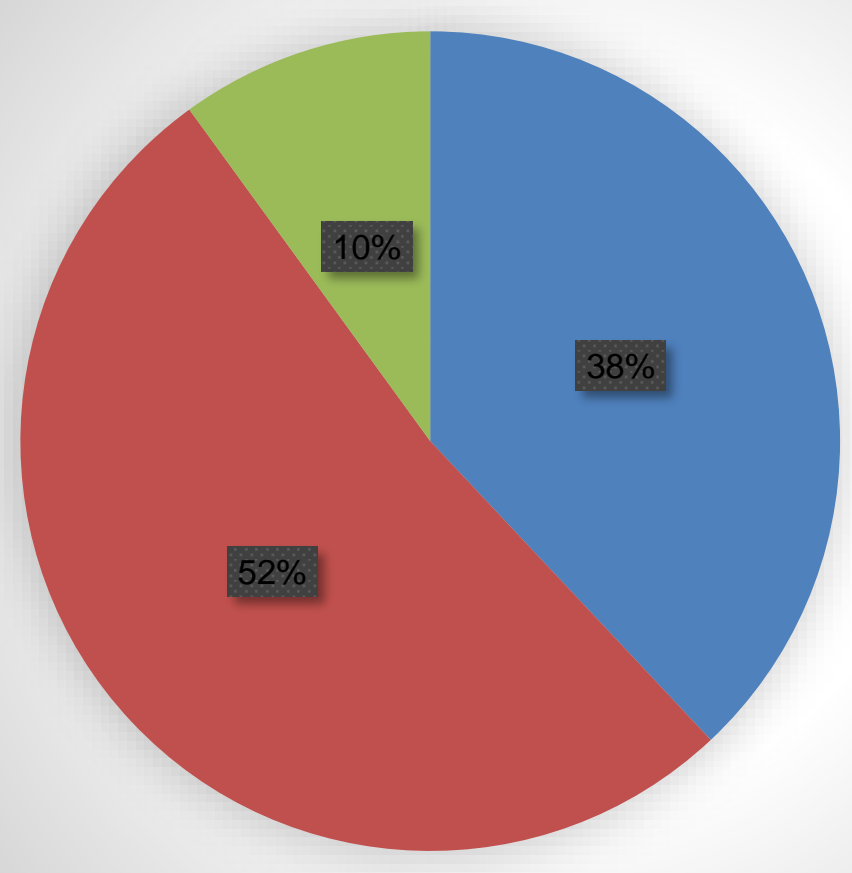

- High result

- Middle result

- Low result

Fig. 2. Results of using Mentimeter in student project activities in 2019.

In 2019, the percentage of people with high results reached 38, with an average of 52 . At the same time, accordingly, the number of students with low results becomes lower.

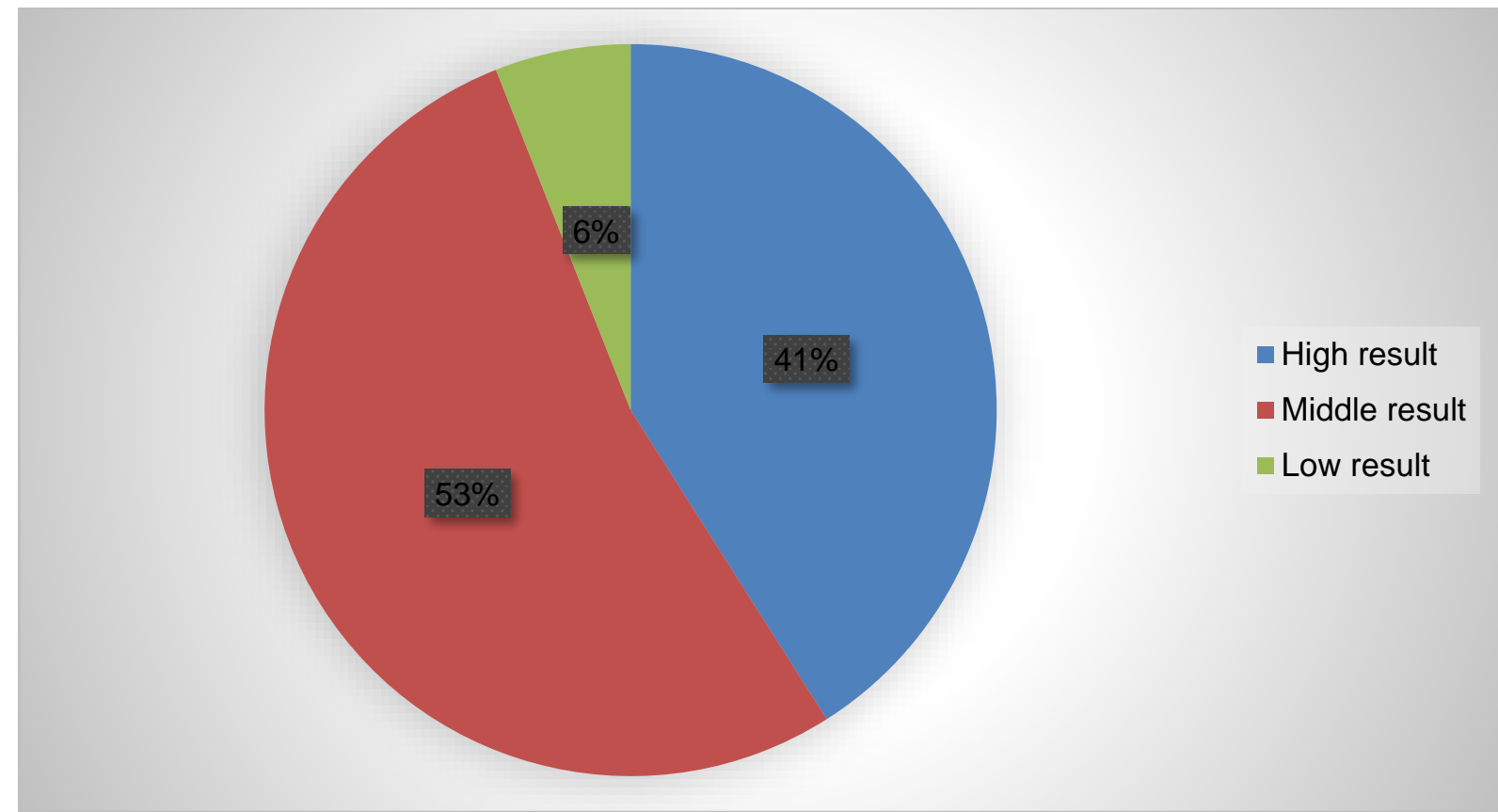

Fig. 3. Results of assessing the use of Mentimeter in student project activities in 2020. 
Using Mentimeter shows that students love this resource for conducting surveys. By 2020, the percentage of students with high and average results has increased.

Creating presentations with polls and polls allowed students to fully master the functionality of Mentimeter.

Students also assessed the effectiveness of Mentimeter on their own. They were asked to answer the question: "How do you assess the use of Mentimeter in the process of carrying out your project activities?" from 1 to 4 points.

Where 1 - the tool does not unambiguously show its effectiveness in project activities; 2 - the instrument does not show its effectiveness to a greater extent; 3 - the tool is more effective in project activities; 4 - the tool shows the absolute effectiveness in project activities.

At the same time, it was indicated that the effectiveness includes several provisions. The main provisions on which the students relied are reflected in table 1.

\section{Table 1.}

Key points about the performance of Mentimeter in project activities.

\begin{tabular}{cl}
\hline No. & \multicolumn{1}{c}{ Characteristic } \\
\hline 1 & Through the use of Mentimeter, I receive prompt feedback from respondents \\
\hline 2 & $\begin{array}{l}\text { I can quickly create the survey and quiz I want because Mentimeter has the right } \\
\text { set of tools }\end{array}$ \\
\hline 3 & $\begin{array}{l}\text { The target audience does not have technical problems when taking the survey, } \\
\text { so I get the results on time }\end{array}$ \\
\hline 4 & I can easily interpret the received data \\
\hline 5 & I can use the created questionnaires an unlimited number of times \\
\hline
\end{tabular}

The figure shows the results of students' answers on the use of Mentimeter in student projects of different levels. 


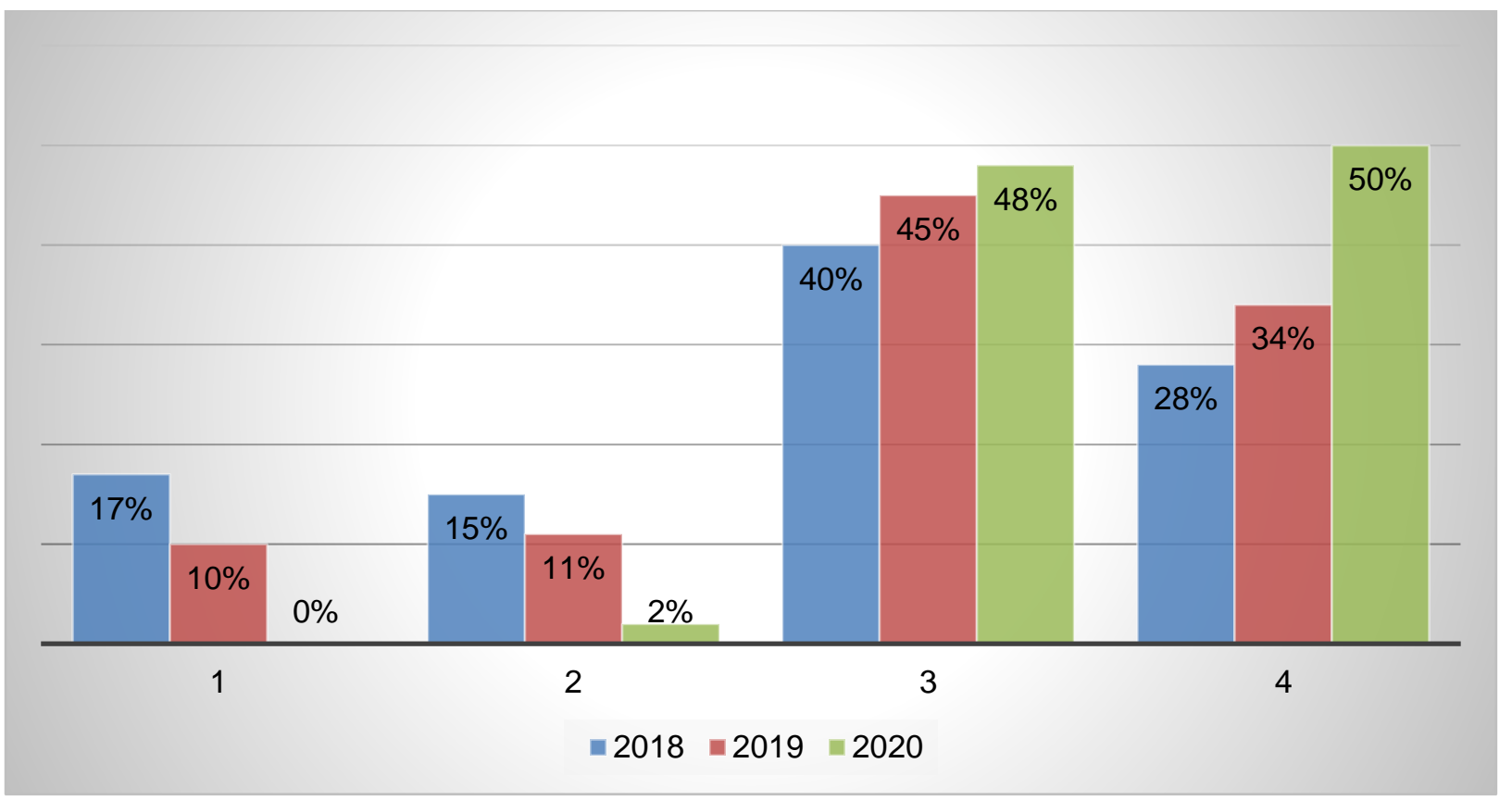

Fig. 4. The results of students' answers on the question of the effectiveness of Mentimeter in project activities.

An increase in the number of participants who noted the high performance of Mentimeter in project activities was recorded.

\section{Conclusions}

The electronic tools considered in the article represent the possibility of automatic processing of results, screen presentation of information for clarity and timely reflection of students on the results obtained.

Mentimeter allowed to achieve maximum involvement of students in the discussion of professional issues, allowed students to independently organize surveys among respondents to implement their projects.

The use of electronic tools turns the survey into a live dialogue with the audience. Conducting surveys in the student environment through electronic educational resources expands the possibilities for the formation of a highly qualified specialist in demand on the labor market.

\section{Bibliographic references}

Aniskin, V. N., Korostelev, A. A., Lvovna, B. A., Kurochkin, A. V., \&Sobakina, T. G. (2020). Teaching potential of integrated learning technologies Smart, Stem and Steam. Revista De La Universidad Del Zulia, 11(29), 328-336. 
Arbeláez-Campillo, D., Tatsiy, V., Rojas-Bahamón, M., \& Danilyan, O. (2020). Contributions of critical thinking as a form of participation and political deliberation. Amazonia Investiga, 9(27), 5-12. https://doi.org/10.34069/Al/2020.27.03.1

Bulaeva, M. N., Vaganova, O. I., Koldina, M. I., Lapshova, A. V., \& Khizhnyi, A.V. (2018). Preparation of Bachelors of Professional Training Using MOODLE. Advances in intelligent systems and computing, 622, pp. 406-411.

Bogdanova, A.N., \& Fedorova, G.A. (2020). The use of interactive surveys in lectures on the discipline "information and communication technologies and media information literacy". Bulletin of the Siberian Institute of Business and Information Technologies, (1 (33)), 4-9.

Chulanova, O.L. (2018). Foresight sessions as an innovative tool for strategic management and the work of project teams. Materials of the Afanasyev Readings, (1 (22)), 28-36.

Dronova, E.N. (2020). Elements of mobile learning in higher education: developing and conducting online surveys using the internet service Kahoot. Problems of modern education, (4), 196-208.

Dobudko, T.V., Korostelev A.A., Gorbatov S.V., Kurochkin A.V., \& Akhmetov L.G. (2019). The organization of the university educational process in terms of digitalization of education. Humanities and Social Sciences Reviews, 7(4), pp. 1148-1154.

Demidov, A.A. \& Tretyakov A.L. (2016a). A network model of centers for ethical and legal education and civil-patriotic education and media education centers based on school libraries: the need to create, opportunities and real prospects, Media Education (Mediaobrazovanie), 3, pp. 16-22.

Demidov, A.A., \& Tretyakov, A.L. (2016b) Centers for ethical and legal information and media education based on the school library - an innovation in the implementation of the Federal State Educational Standard and infrastructure for the development of information and legal culture of children and youth. Media Education (Mediaobrazovanie), 2, pp. 21-33.

Ivanova, N., \& Korostelev, A. (2019). The impact of competitive approach on students' motivation in sport. Amazonia Investiga, 8(18), 483-490. Retrieved from https://amazoniainvestiga.info/index.php/amazonia/article/view/362

Kidina, I. M. (2020). Management of the pedagogical collective in the conditions of implementing distance learning. Baltic Humanitarian Journal. (Baltic Humanitarian Journal), Vol. 9 No 4 (33), pp. 93-96.

Kharytonov, E., Kharytonova, O., Tolmachevska, Y., Fasii, B., \& Tkalych, M. (2019). Information Security and Means of Its Legal Support. Amazonia Investiga, 8(19), 55-265. Retrieved https://amazoniainvestiga.info/index.php/amazonia/article/view/227

Kiseleva, O., Lebedev, A., Pinkovetskaia, I., Rojas-Bahamón, M., \& Arbeláez Campillo, D. (2019). Specialization and concentration of small and medium enterprises employees: Russian data. Amazonia Investiga, 8(20), 6-15. Retrieved from https://amazoniainvestiga.info/index.php/amazonia/article/view/59

Nagovitsyn, R. S., Vaganova, O. I., Kutepov, M. M., M. L. N., Kosenovich, O. V, Moeseev, Yu. V., Vorotova, M. S., \& Osipov, A. Y. (2020). Interactive Technologies in 
Developing Student's Motivation in Physical Education and Sport. International Journal of Applied Exercise Physiology, 9(6), 78-85.

Pichugina, G.A., \& Bondarchuk, A.I. (2019). Structure of the training case in the organization of the educational process. Humanitarian Balkan Research, 2(4), pp. 5-7.

Pinkovetskaia, I., Berezina, N., \& Sverdlikova, E. (2020). The main reasons for the exit of entrepreneurs from business. Amazonia Investiga, 9(26), 68-73. https://doi.org/10.34069/Al/2020.26.02.7

Rojas-Bahamón, M.J., Aguilar-Cruz, P.J., \& Arbeláez-Campillo, D.F. (2020). Curricular integration as a strategy to strengthen the educational process in public institutions in COVID-19 times. Revista Inclusiones, 7 (num Especial), pp. 233-241.

Shashlo, N., Petruk, G., \& Korostelev, A. (2018). Determinants of integration interaction among the subjects of the entrepreneurial innovation ecosystem of macro region. Amazonia Investiga, 7(13), 351-363. Retrieved from https://amazoniainvestiga.info/index.php/amazonia/article/view/569

Smirnova, Z.V., Vezetiu, E.V., Vaganova, O.I., Pluzhnikova, E.A., \& Akimova, I.V. (2020). Automated knowledge management through e-testing. International Journal of Advanced Trends in Computer Science and Engineering, 9(3), pp. 3256-3260.

Shcerbakova, E.V., \& Shcerbakova, T. N. (2019). Experience of Use of Remote Computer Technologies at The Organization of Independent Work of Students in The Conditions of a Mark and rating system. Baltic Humanitarian Journal. (Baltic Humanitarian Journal), Vol. 8, No 4 (29), pp. 192-195.

Tezer, M., Yildiz, E.P., Masalimova, A.R., Fatkhutdinova, A.M., Zheltukhina, M.R., \& Khairullina, E.R. (2019). Trends of augmented reality applications and research throughout the world: meta-analysis of theses, articles and papers between 20012019 years. International Journal of Emerging Technologies in Learning, 14(22), pp. 154-174.

Vaganova, O.I., Korostelev, A.A., Smirnova, Z.V., Abramova, N.S., Dolmatov, S.N. (2019). Improving teachers' professionalism through the development of creativity. International Journal of Innovative Technology and Exploring Engineering, 8(8), pp. 630-634.

Vaganova, O. I., Petrozitskaya, I. A., Snatovich, A. B., Odarich, I. N., \& Kirillova, I. K. (2020). Heuristic technologies of training in professional education. Amazonia Investiga, 9(27), 509-517. https://doi.org/10.34069/Al/2020.27.03.55

Yarygin, O.N., Korostelev, A.A., Akhmetov, L.G., \& Maseleno, A. (2019). Modeling of competence as a tool of goal setting for education in modern society. International Journal of Recent Technology and Engineering, 7(6), pp. 72-77. 